PIOTR DUDZIKOWSKI - LUBLIN

\title{
O PROFILAKTYCE I ZABEZPIECZANIU MATERIAŁÓW ARCHIWALNYCH
}

Jest rzeczą oczywistą dla tych, którzy choć raz rozumnie, z pokorą i szacunkiem trzymali jakąkolwiek książkę w ręku, że papier, na którym owa książka jest napisana, jak wszystkie rzeczy tego świata jest nietrwały i wcześniej czy później wróci do natury jako przysłowiowy proch. Ale im więcej szacunku i zrozumienia mamy dla rzeczy, które dane jest nam trzymać w dłoniach, tym ich pamięć i żywotność będą trwały dłużej. Wystarczy zdać sobie sprawę z tego, że każda książka, każdy papier ma swoją własną historię, chciałoby się rzec - żyje swoim własnym życiem i podlega pewnemu nieuchronnemu prawu - prawu natury.

$\mathrm{Na}$ wstępie należałoby wyjaśnić kilka spraw. Mianowicie najważniejsza w pracy z papierem jest świadomość tego, czym ten papier jest, z czego się składa, jaka jest jego struktura i jakie procesy zachodzą wewnątrz tej struktury oraz, że papier traci swoją pierwotną świetność i zaczyna niszczeć. Kolejną „najważniejszą" rzeczą jest świadomość jak temu wszystkiemu zapobiec i jak najdłużej zachować pierwotne własności fizyczno-chemiczne papieru. Trzecią „najważniejszą" rzeczą jest zrozumienie tego, że zasady te są ,żelazne” i każde ich naruszenie prowadzi w konsekwencji - czasami rozłożonej w czasie - do nieocenionych strat i biotoksykologicznych pułapek czyhających na nasze zdrowie. Wreszcie czwarta „najważniejszą" rzeczą jest świadomość tego, że papier, który często - w perspektywie naszego jakże fascynującego życia - jest tylko niewiele, bądź zupełnie nic nieznaczącą kartką, dla tych, którzy będą żyli po nas, być może będzie świadectwem naszej historii, naszej kultury, obyczajowości, wrażliwości czy co tam jeszcze zwykliśmy nie zawsze świadomie zostawiać na papierze.

Papier jest to tworzywo formowane $\mathrm{z}$ wodnej zawiesiny włókien roślinnych (np.: len, bawełna, konopia, juta), których dominującym składnikiem jest celuloza. Włókno roślinne jest zbudowane z warstw, w których rozlokowane są mini włókienka, czyli makrofibryle, złożone z jeszcze drobniejszych elementów włóknistych, czyli mikrofibryl. Ich chemiczną strukturę stanowią łańcuchy celulozy. Celuloza jest związkiem organicznym węgla, wodoru i tlenu, które tworzą dużą cząsteczkę o budowie włóknistych łańcuchów; jest wielocukrem złożonym, któ- 
rego pojedynczymi ogniwami są cząsteczki bezwodnika glukozy. Ogniwa połączone ze sobą tworzą pojedyncze, długie na kilka milimetrów, łańcuchy. Włókna te w wielkim skrócie opisać by można jako „cukrowe rurki”.

Obecnie podstawowym surowcem włóknistym dla papiernictwa jest drewno. Masy celulozowe $\mathrm{z}$ drewna otrzymuje się $\mathrm{w}$ sposób mechaniczny przez ścieranie oraz w sposób chemiczny, w którym drewno poddawane jest działaniu chemikaliów w podwyższonej temperaturze. Ponadto $\mathrm{w}$ procesie maszynowej produkcji papierów drukowanych i do pisania wprowadza się do masy papierowej białe pigmenty - wypełniacze. Są one tańsze od włókien celulozowych, a zatrzymując się w strukturze papieru poprawiaja jego właściwości fizyczne. Jako wypełniacz stosuje się przede wszystkim kaolin, a także wypełniacze zasadowe - węglan wapnia, kredę i marmur.

W Polsce historia papiernictwa zaczyna się u schyłku wieków średnich. Pierwszą polską papiernią o udokumentowanej historii była czerpalnia założona w 1491 roku w Prądniku Czerwonym koło Krakowa, na terenie należącym do klasztoru świętego Ducha (obecnie jedna z dzielnic miasta). Produkowany wówczas papier zaspokajał nie tylko krajowe potrzeby, ale docierał także do krajów ościennych, między innymi na Węgry, Mołdawię i do Państwa Moskiewskiego. Do najstarszych polskich papierni należały młyny we Wrocławiu, Świdnicy, Nysie i Raciborzu. Później powstały kolejne w okolicy Poznania, Wilna, Lublina, Warszawy i Krakowa. Najstarszą polską papiernią działającą do dnia dzisiejszego jest założona w 1774 roku papiernia w Jeziornie koło Warszawy. Te najdawniejsze polskie papiery wykonywane były wyłącznie z włókien lnianych - zużytych szmat, lin, worków i powrozów. Od XVII wieku do wyrobu papieru zaczęto stosować włókna juty.

Brak naturalnego surowca włóknistego dla papiernictwa oraz konieczność pozyskiwania masy włóknistej z surowców wtórnych spowodował, że już we wczesnym okresie upowszechniania się papiernictwa w Europie dużym problemem było zapewnienie dostaw szmat dobrego gatunku do wyrobu papieru. Przeprowadzone badania nad właściwościami papieru produkowanego w Polsce od XVI do XVIII wieku wykazały, że w pierwszej połowie XVI wieku 94\% wytwarzanego papieru określa się jako dobry oraz bardzo dobry, w pierwszej połowie XVII wieku zaledwie $46 \%$ to papier dobry, natomiast w pierwszej połowie XVIII wieku już tylko $39 \%$ papierów można określić jako dobre. Pozostałą część starodruków wytłoczono na papierze ocenianym jako średni lub zły. ${ }^{1}$ Pomimo wprowadzania zakazów wywozu z kraju surowców do produkcji papieru i znacznego wzrostu wydajności produkcji, dzięki licznym usprawnieniom technicznym i organizacyjnym, papieru produkowano wciąż za mało. Prawdziwą rewolucją w papiernictwie okazało się wykorzystanie w produkcji nowego surowca. Francuski uczony Rene Antoine Ferchault de Reaumur opracował technologię, umożliwiajacą wykorzystanie drewna do wyrobu papieru. Już w latach osiemdziesiątych XVIII wieku we Francji w jednej z papierni zaczęto wytwarzać na skalę produkcyjną masę włóknistą

${ }^{1}$ J. Siniarska-Czaplicka, Próba określenia gatunków papieru druków tłoczonych na ziemiach Rzeczypospolitej w XVI - XVIII wieku, „Rocznik Biblioteki Narodowej”, 17-18 (1986) s. 159-171. 
pochodzącą z drewna topolowego, z której następnie produkowano papier. Pokonawszy problemy surowcowe papiernie mogły rozwijać swoją produkcję na dużą skalę. Z początkiem XIX wieku, dzięki pełnemu zmechanizowaniu produkcji, ruszyły pierwsze produkcyjne zakłady papiernicze. W 1800 roku Matthias Koops rozpoczął produkcję papieru z masy włóknistej otrzymywanej ze słomy, wkrótce także $\mathrm{z}$ drewna drzew odmian ubogich $\mathrm{w}$ substancje żywiczne. ${ }^{2}$

Na początku XIX wieku, gdy papier zaczęto produkować maszynowo, do jego zaklejania używano kleju kalafoniowego - żywicznego, rozpuszczanego w ałunie - siarczanie glinu. ${ }^{3} \mathrm{~W}$ wyniku tego, już w czasie formowania papieru na sicie maszyny papierniczej - czyli niejako w momencie jego narodzin - wprowadzano czynnik kwasowy. Przyspieszał on proces degradacji celulozy prowadząc do spadku właściwości fizyko-chemicznych papieru, a w konsekwencji, po jego stuletniej historii, często do jego całkowitej degradacji. Dramatu dopełnił Claude Luis Berthollet, który na początku XIX wieku odkrył właściwości bielące chloru (Cl) i opracował metodę bielenia parami chloru tkanin, wosku i masy papierniczej. Papier bielony metodą Bertholleta dosłownie „rozpadał się w oczach” w niedługim czasie po wytworzeniu.

Papier kwaśny najpierw żółknie i kruszeje, a w związku z tym łatwiej ulega uszkodzeniom mechanicznym. Dokumenty czy książki z takiego papieru mają często postrzępione brzegi a ich karty łatwo się rwą. U schyłku swego życia stają się brązowe i kruszą się jak opłatek. Proces ten można zaobserwować we wszystkich bibliotekach i archiwach na całym świecie, a każdy z nas na pewno nie jeden raz miał w ręku leciwą książkę, nad której kondycją i nieuchronnym losem można jedynie zapłakać.

Dziś również wytwarza się papier w środowisku kwaśnym. Decyduje o tym taniość i skuteczność tej metody. Powszechnie stosuje się ją do produkcji mocnych papierów i kartonów do opakowań, co do których nie istnieją wymogi odnośnie długotrwałej odporności na starzenie. Stopień zaklejenia papieru jest też miarą jego wodoodporności, czyli spowolnienia wnikania wody i roztworów wodnych w głąb papieru. Na papierze należycie zaklejonym można pisać atramentem i właściwie go zadrukować, co szczególnie ważne jest przy druku offsetowym. Należy jednak podkreślić, że w przypadku papierów do drukowania i pisania ważniejszą rolę odgrywają papiery zaklejane w środowisku obojętnym lub zasadowym klejami syntetycznymi. Podnosi to niestety koszt produkcji takiego papieru, ale za to znacznie przedłuża jego żywotność.

W Polsce podjęto badania nad możliwością produkowania papieru w środowisku zasadowym w latach sześćdziesiątych. Pierwszy taki papier zaczęto produkować na początku lat dziewięćdziesiątych. Dziś istnieje międzynarodowa norma

${ }^{2}$ D. Rams, D. Jarmińska, Włókna papiernicze - historia i identyfikacja, „Notes konserwatorski”, 2 (1999) s. 157.

${ }^{3}$ Zaklejanie papieru klejem ałunowo-żywicznym, czyli w środowisku kwaśnym, którego ph wynosi ok. 4-5 wynalazł w 1807 roku Morttz Friedrich Illig. Technologia ta upowszechniła się szybko w całej europie wypierając produkcję rękodzielniczą. Wzór sumaryczny ałunu (siarczanu glinu): $\mathrm{Al}_{2}\left(\mathrm{SO}_{4}\right)_{3}$. W obecności wilgoci z ałunu tworzy się kwas siarkowy $\left(\mathrm{H}_{2} \mathrm{SO}_{4}\right)$. 
definiująca i określająca jakość oraz trwałość papieru, w myśl której „Trwałym papierem nazywa się taki papier, którego własności charakteryzujące możliwość odczytu i użytkowania w warunkach typowych dla bibliotek $i$ archiwów podczas długotrwałego przechowywania w bibliotekach, archiwach lub innych chronionych środowiskach nie ulegają zmianie lub zmiany te są niewielkie. Dokumentem nazywa się papier, na którym zarejestrowano informację". Norma ta precyzuje wymagania dla papieru trwałego na dokumenty, przede wszystkim w odniesieniu do papierów przeznaczonych do pisania, drukowania a także kopiowania. Symbolem graficznym spełnienia wymagań tej normy jest znak nieskończoności (przewróconej ósemki) umieszczony w okręgu.

Aby powstała informacja, oprócz nośnika, czyli np.: papieru potrzebne jest jeszcze medium, czyli np: atrament. $Z$ łacińskiego: atramentum, czyli czernidło - płyn barwny służący do pisania. Niestety oprócz niewątpliwych zalet atrament ma także „kwaśne” wady.

Istnieją dwa zupełnie różne rodzaje atramentów. Pierwszy to atrament węglowy, stosowany od starożytności aż do XII wieku, produkowany z węgla drzewnego, brunatnego lub sadzy zmieszanych z gumą arabską. Drugi, popularniejszy od XII wieku, to atrament galusowy, powstały z roztworu kwasów taninowych i soli żelaza. Oba typy atramentów były stosowane w średniowiecznych rękopisach. Z pewnością inkaustem galusowym pisano jeszcze przed III stuleciem naszej ery, ale nie było tradycji zapisywania sposobu jego otrzymywania, aż do początku XII wieku. Od tego czasu rzemieślnicy opisywali atrament galusowy i prawdopodobnie prawie wszystkie późniejsze manuskrypty były tworzone za jego pomocą.

Galas miażdżyło się i namaczało przez parę dni w deszczówce (bądź zamiast tego w winie albo occie) na słońcu lub przy ogniu, dzięki czemu otrzymywano potrzebny przy produkcji atramentu roztwór, używany również w procesie garbowania. Drugi składnik to wspomniana sól żelazas. Pod koniec XVI wieku ten związek chemiczny otrzymywano prawdopodobnie przez zalewanie kwasem siarkowym starych gwoździ, filtrowaniu cieczy i mieszaniu jej z alkoholem ${ }^{6}$. Na bazie średniowiecznych receptur powstał pierwszy, trwały i prosty w użyciu atrament. Jego wynalazcą był niemiecki producent perfum August Leonardi. Atrament ,posiadł" niespotykane wcześniej zalety: był odporny na działanie wody, nie blaknął $\mathrm{i}$ - jak się wtedy zdawało, nie niszczył papieru. Kwaśny atrament powoduje tak zwane wżery atramentowe. Mówiąc dosłownie - wypala na wylot dziury w papierze w miejscy gdzie zetknął się z kartką. i niestety jest to powszechnie zauważalne uszkodzenie papieru, nie tylko nowożytnego ale i całkiem współczesnego ${ }^{7}$. Stosowane współcześnie atramenty wytwarzane są przeważnie z rozpuszczalnych $\mathrm{w}$ wodzie lub alkoholu barwników syntetycznych.

${ }^{4}$ ISO 9706:1994, Information and documentation - Paper for documents - Requirements for permanence (Informacja i dokumentacja - Papier na dokumenty - Wymagania odnośnie trwałości).

${ }^{5}$ Dokładniej uwodniony siarczan żelazawy, tzw. witriol żelazny, wydobywany w Hiszpanii przez odparowywanie wody z pokładów żelaza w glebie.

${ }^{6}$ Co tłumaczyłoby kwaśne, żrące właściwości nowożytnych atramentów powodujących tzw. wżery atramentowe.

${ }^{7}$ Mam tu na myśli dokumenty wytworzone XIX i XX w. do lat 40. włącznie. 
Kolejną niezwykle ważną rzeczą dla informacji jest nie tylko jej utrwalenie, ale i stosowne zabezpieczenie. Dlatego jedną z dziesiątek naprawdę pożytecznych rzeczy, jakimi zajmuje się i do jakich zostało powołane archiwum ${ }^{8}$, oprócz gromadzenia, przechowywania, opracowania i udostępniania dokumentów - jest właśnie zabezpieczanie 9 . I od tego w dużej mierze zależy długowieczność oraz stan zachowania materiałów archiwalnych.

Nie pojawiałyby się większe problemy gdyby wszystkie archiwa miały rozmiar naszych „,domowych” księgozbiorów, nad którymi na pewno da się zapanować i należycie o nie troszczyć. Jest jednak problem, kiedy zbiór dokumentów ma kilkadziesiąt, kilkaset czy nawet kilka tysięcy metrów bieżących „papieru”, w różnym wieku, różnej jakości i kondycji. Na ową kondycję dokumentów, tak jak na nasze własne samopoczucie, ma wpływ bardzo wiele czynników. Na przykład warunki klimatyczne - mówiąc w przenośni i dosłownie - pogoda w magazynie, w którym znajdują się akta - czyli temperatura i wilgotność powietrza, sposób w jaki są poustawiane półki i same akta, dostęp i rodzaj światła oraz zanieczyszczenia różnego pochodzenia, jakie znajdują się w powietrzu, a także w strukturze samego papieru. Dlatego dla zapewnienia możliwie największego bezpieczeństwa naszym księgom, książkom i aktom konieczne jest stworzenie możliwie najdogodniejszych i bezpiecznych warunków przechowywania, dzięki którym - czego na pewno wszyscy sobie życzymy - ich ,samopoczucie” przez długie lata będzie można określić jako dobre.

Istnieje wiele norm, zaleceń i przepisów prawnych regulujących sposób właściwego zabezpieczania materiałów archiwalnch, odnoszących się do tak szcze-

${ }^{8}$ Pisząc o archiwum mam na myśli nie tylko instytucję, ale pewien uporządkowany zbór dawnych pism i nieaktualnych dokumentów lecz wartych zachowania, przechowywanych w określonym powołanym do tego miejscu. Archiwum - łac. archivum, gr. archeion - siedziba urzędu, rządu później budynek, w którym przechowywano akta urzędowe. Słownik wyrazów obcych, red. J. Tokarski, Warszawa 1980, s. 45.

${ }^{9}$ Zasady ochrony narodowego zasobu archiwalnego określają następujące normy prawne:

- Polska Norma PN-ISO 11799, Informacja i dokumentacja. Wymagania dotyczące warunków przechowywania materiałów archiwalnych i bibliotecznych, Warszawa, czerwiec 2006.

- Konwencja w sprawie ochrony dóbr kultury w razie konfliktu zbrojnego, Dz. U. 1957, nr 46, poz. $46,211$.

- Ustawa o ochronie dóbr kultury i o muzeach z dn. 15 lutego 1962.

- Ustawa o narodowym zasobie archiwalnym i archiwach z dn. 14 lipca 1983, Dz. U. 1983, nr 38 , poz. 173 , art.: $6,12,49,50,52,55$.

- Ustawa o ochronie dóbr i mienia z dn. 22 sierpnia 1997, Dz. U. 1997, nr 144, poz. 740.

O czynnikach biologicznych i związanych z nimi zagrożeniach: Dyrektywa UE 2000/54/WE.

W roku 1986 pomiędzy Episkopatem Polski oraz Ministerstwem Kultury i Sztuki podpisano porozumienia: Uzgodnienie $w$ sprawie zasad organizacji ochrony sakralnych i kościelnych dóbr kultury na wypadek zagrożenia bezpieczeństwa państwa oraz Zasady prowadzenia prac przygotowawczych $w$ zakresie ochrony sakralnych $i$ kościelnych dóbr kultury na wypadek zagrożenia bezpieczeństwa państwa. Ponadto między Stolicą Apostolską a Rzeczpospolitą Polską zawarty został 28 lipca 1993 r. konkordat, w którym strony uzgodniły potrzebę wzajemnej współpracy w zakresie ochrony sakralnych i kościelnych dóbr kultury oraz dokumentów archiwalnych o wartości historycznej i artystycznej. 
gółowych kwestii jak: budynek archiwum, jego lokalizacja, ogólna specyfika pomieszczn magazynowych a w tym kwestie ścian, podłóg, oświetlenia, regałów archiwalnych, czy wreszcie instalacji elektrycznej i c.o. oraz przepisów p.poż. i bhp. Jednak warto mimo wszystko zwrócić szczególną uwagę na niektóre problemy z zakresu profilaktyki i zabezpieczania materiałów archiwalnych.

Temperatura powietrza $\mathrm{w}$ magazynie jest bardzo ważnym czynnikiem, utrzymywana na właściwym poziomie, czyli $14^{\circ} \mathrm{C}-18^{\circ} \mathrm{C}$, (przy czym ważne jest, aby dobowe wahania temperatury nie wynosiły więcej niż $\pm 1^{\circ} \mathrm{C}$ ) znacznie przedłuża żywotność papieru. Zdawałoby się, że $14^{\circ} \mathrm{C}$ to niekoniecznie sprzyjające warunki do pracy. Niestety komfort archiwisty jest tu na drugim planie. Dobro, kondycja i żywotność dokumentów jest obliczana na znacznie dłużej, niż perspektywa kariery zawodowej jakiegokolwiek archiwisty. My - chciałoby się rzec melancholijnie - jesteśmy tylko przechodniami wśród archiwalnych tomów, które nie tylko z założenia - ale i z potrzeby - mają być wieczne. We względnie niskiej temperaturze wszystkie procesy chemiczne zachodzące w strukturze papieru, w tym kwaśnienie, zachodzą znacznie wolniej. Niskie temperatury również ograniczają rozwój mikroorganizmów oraz owadów. Oczywiście przy założeniu, że został spełniony jeszcze jeden, najważniejszy warunek.

Wilgotność względna powietrza $(\mathrm{RH})$ to czynnik, który w bezpośredni sposób wpływa na stan fizyczny papieru. Przyjmuje się, że wartości najbezpieczniejsze dla archiwaliów to $40-60 \%$ RH, (przy czym ważne jest, aby dobowe wahania wilgotności względnej nie wynosily więcej niż $\pm 3 \% \mathrm{RH}$ ). Poniżej wartości $40 \%$ wilgotności względnej powietrza papier zostaje nadmiernie wysuszony, a co za tym idzie staje się kruchy i łamliwy. Powyżej wartości $60 \%$ wilgotności względnej powietrza, dzięki swoim właściwościom higroskopijnym papier chłonie wilgoć, zwiększa swoją objętość i deformuje się. Nadmierna wilgotność sprzyja rozwojowi mikroorganizmów. Powodują one groźne dla papieru, często nieodwracalne zniszczenia, a w procesie przemiany materii produkują groźne substancje, szkodliwe nie tylko dla papieru, ale również dla naszego zdrowia. Ponadto wilgoć jest jednym z czynników wywołujących i przyspieszających zmiany chemiczne w strukturze samej celulozy i związane z nimi poważne zniszczenia.

Utrzymanie tych dwóch parametrów - temperatury i wilgotności względnej powietrza - na stałym poziomie, zwłaszcza w przypadku braku odpowiedniej klimatyzacji, jest niezwykle trudne. Niemniej obowiązkiem osób odpowiedzialnych za stan zbiorów jest stała analiza poziomu temperatury i wilgotności względnej oraz w miarę możliwości „ręczne” regulowanie tych parametrów. Odpowiednio kontrolowane parametry klimatyczne stwarzają warunki, w których drobnoustroje (poza bardzo nielicznymi) nie mogą się rozwijać. $Z$ czasem prowadzi to do zaniku żywotności grzybni i zarodników. Niestety objawy ich działalności pozostają. Problem temperatury i wilgotności to jednak nie wszystko.

Mechanizm działania czynników szkodliwych jest różnoraki i przebiega w różny sposób w różnych okolicznościach, niestety efekt zawsze jest ten sam 
- destrukcja materiałów archiwalnych ${ }^{10}$. Dlatego wszelkie próby wyeliminowania tych czynników to działania jak najbardziej właściwe i potrzebne. Jak już wspominałem, papier, który jak wszystkie materialne rzeczy na świecie, w swojej istocie jest substancją chemiczną i w związku z tym podlega prawom chemii $\mathrm{i}$ wchodzi w reakcję z różnymi czynnikami fizycznymi i chemicznymi.

Światło jest czynnikiem wywołującym zmiany we wszystkich rodzajach zbiorów bibliotecznych i archiwalnych, a głębokość tych zmian uzależniona jest od rodzaju światła, jego natężenia i czasu ekspozycji. Proces degradacji dotyczy wszystkich materiałów składających się na jednostkę archiwalną - czyli papieru, klejów, tkanin introligatorskich, atramentów i pigmentów (np. w ilustracjach barwnych). Destrukcja ta powodowana jest zarówno przez światło dzienne, które przenika do wnętrza budynku, jak i przez światło sztuczne stosowane do oświetlania pomieszczeń. Szczególnie szkodliwe jest intensywne oświetlenie książek, dokumentów, map czy czasopism w trakcie wykonywania prac związanych na przykład z kserowaniem. Pod wpływem promieniowania nadfioletowego (UV) papier zaczyna żółknąć, staje się kruchy i łamliwy. Dzieje się tak, ponieważ światło jako fala elektromagnetyczna, jest czynnikiem wpływającym na depolimeryzację włókien celulozy, co prowadzi bezpośrednio do ich osłabienia w skutek reakcji chemicznej - zwykle utleniania. Bezpośrednim efektem działania promieni UV może być przekształcenie się związków chemicznych w inne związki, zerwanie wiązań chemicznych bądź całkowita degradacja substancji. Promieniowanie UV jest również przyczyną dysocjacji związków utleniających i tworzenia się wysoce reaktywnych wolnych rodników. Fotooksydacja następuje przez reakcję z rodnikami $\mathrm{OH}$, ozonem $(\mathrm{O} 3)$ oraz $\mathrm{NO} 3$, które stanowią najważniejsze fotoutleniacze. Zawartość rodników OH i ich zdolność do szybkiej reakcji ze związkami zależy od intensywności światła słonecznego. Fotodegradacja związków jest uznawana za wstępny proces, po którym następuje rozkład związków przez mikroorganizmy. Działanie światła ułatwia powstawanie związków częściowo utlenionych, które są bardziej podatne na procesy biodegradacji niż związki macierzyste ${ }^{11}$.

Zanieczyszczenia chemiczne stanowią niestety nieodłączny składnik powietrza atmosferycznego. Również i one, przenikając do magazynów bibliotecznych i archiwalnych, niekorzystnie wpływają na zgromadzone zbiory. Najbardziej destrukcyjny wpływ na papier mają tlenki siarki i azotu, a także formaldehyd, ozon, węglowodory aromatyczne, związki chloru i różnego rodzaju pyły. Podobnie jak

\footnotetext{
${ }^{10}$ Zjawisko niszczenia różnych materiałów w tym archiwalnych naszą dwie nazwy: biodegradacja i biodeterioracja. Biodegradacja to rozkład mikrobiologiczny korzystny z punktu widzenia gospodarki człowieka, np. degradacja składników ścieków, pestycydów w glebie itp. Natomiast biodeterioracja to niszczenie materiałów potrzebnych człowiekowi np.: kosmetyków, kauczuku, tekstyliów, farb, drewna tworzyw sztucznych papieru itp., przez organizmy żywe. Termin ten przyjął się już dawno w krajach anglojęzycznych w języku polskim nie zadomowił się na, tyle aby go można było potocznie używać. A. B. Strzelczyk, J. Karbowska-Berent, Drobnoustroje i owady niszczace zabytki i ich zwalczanie, Torun 2004, s. 10.

${ }^{11}$ A. Kot-Wasik, D. Dąbrowska, J. Namieśnik, Degradacja zwiqzków organicznych w środowisku, w: Nowe horyzonty $i$ wyzwania $w$ analityce i monitoringu środowiskowym, red. J. Namieśnik, W. Chrzanowski, P. Szpinek, Gdańsk 2003, s. 704.
} 
w przypadku światła, zanieczyszczenia powietrza powodują reakcje chemiczne, w rezultacie których powstają nieodwracalne, szkodliwe dla obiektów papierowych zmiany prowadzace nawet do całkowitej degradacji.

Z zanieczyszczeń atmosferycznych szczególnie szkodliwy jest dwutlenek siarki (SO2). Wynika to między innymi z łatwości, z jaką papier absorbuje go z powietrza. Wystarczy obecność jednej cząstki SO2 na 2 miliony cząstek powietrza, żeby papier zaczął zmieniać swoje pH. Szkodliwość SO2 dla papieru tłumaczy się w sposób następujący: zaabsorbowany z powietrza dwutlenek siarki, rozpuszczając się w wilgoci zawsze obecnej w papierze, tworząc kwas siarkawy (H2SO3), który skutecznie zakwasza papier.

Stopień zakwaszenia papieru wzrasta, gdy obecne są w nim drobiny metali (a obecne zazwyczaj są), głównie żelaza $(\mathrm{Fe})$ i miedzi $(\mathrm{Cu})$, które katalizują reakcję utleniania tlenem z powietrza $\mathrm{SO} 2$ do $\mathrm{SO} 3$ i sprawiają, że w trakcie rozpuszczania w wilgoci zawartej w papierze powstaje mocniejszy, a więc i bardziej zakwaszający kwas siarkowy (H2SO4). Na dodatek w przeciwieństwie do kwasu siarkawego rozpuszcza się on lepiej w wodzie, praktycznie bez ograniczenia.

Dlatego między innymi należy bezwzględnie usuwać z materiałów archiwalnych wszystkie metalowe elementy takie jak spinacze i zszywki, które korodując przebarwiają papier i jednocześnie wpływają na jego dodatkowe zakwaszenie, a w rezultacie całkowite zniszczenie ${ }^{12}$.

Podobnie przy absorbowaniu z powietrza, a następnie wskutek rozpuszczania $\mathrm{w}$ wilgoci zawartej w papierze dwutlenku azotu (NO2), powstaje mocny kwas azotowy (HNO2).

Ujemny wpływ na zbiory archiwalne ma także ozon (O3) i formaldehyd (HCHO). Duże stężenia ozonu stwierdza się w okresach letnich podczas burzy. Ponadto ozon i formaldehyd pojawiają się w miejscach o silnym natężeniu ruchu motoryzacyjnego. Emitowane przez samochody węglowodory i tlenki azotu pod wpływem światła tworzą między innymi ozon. Ozon utlenia celulozę, w wyniku czego powstaje oksyceluloza, która charakteryzuje się gorszymi własnościami wytrzymałościowymi niż celuloza. Ozon przyspiesza procesy utleniania w papierze, powodując wzrost zakwaszenia, a w rezultacie obniżenie jego trwałości i wytrzymałości. Natomiast formaldehyd działa szkodliwie nie tylko na zbiory, ale i na ludzi, gdyż jest substancją o prawdopodobnym działaniu rakotwórczym oraz alergenem kontaktowym powodującym uczulenia. Duże stężenie formaldehydu stwierdza się, gdy budynek, w którym znajduje się archiwum jest usytuowany w pobliżu ruchliwych ulic oraz po remontach magazynów, gdzie wydziela się z różnych materiałów takich jak farby, lakiery, wykładziny czy produkty drewnopochodne ${ }^{13}$.

Jednak głównym źródłem kwasu we współczesnych papierach jest klej ału-

${ }^{12}$ Podobnie działa na papier atrament żelazowo-galusowy, powodując wspomniane,tak zwane wżery atramentowe. Litery pisane takim atramentem dosłownie „przepalają” papier na wylot sprawiając, że ostatecznie tekst staje się nieczytelny, a w jego miejscu pozostają dziury bądź cała kartka rozpada się na fragmenty.

${ }^{13} \mathrm{D}$. Rams, Wplyw niektórych zanieczyszczeń powietrza atmosferycznego na zbiory bibliotecz$n e$, „Notes Konserwatorski”, 7 (2003) s. 135-136. 
nowo-żywiczny stosowany w procesie produkcji papieru. W obecności wilgoci, z ałunu tworzy się kwas siarkowy. W reakcji hydrolizy kwasowej powstaje jeszcze więcej substancji kwaśnych zdolnych do akumulowania się i ponownego wchodzenia w reakcję, co przyspiesza proces degradacji w postępie geometrycznym.

Problem kwaśnego papieru ma - nie przesadzając - skalę globalną. Większość książek, dokumentów archiwalnych i czasopism wyprodukowanych od połowy XIX wieku do końca lat osiemdziesiątych wieku XX, ma raczej niewielkie szanse na przetrwanie. Są oczywiście podejmowane próby masowego odkwaszania zbiorów (również w Polsce - rządowy program „kwaśny papier” polegający na zakupie i wyposażaniu bibliotek i archiwów w odpowiedni sprzęt oraz na budowaniu świadomości wśród bibliotekarzy i archiwistów). Niestety ciągle jeszcze koszty takich zabiegów w skali masowej są olbrzymie, potrzebny do tego sprzęt mało powszechny i bardzo drogi, a ponadto ilość kwaśnego papieru, który wymaga ratowania jest tak ogromna, że o kolejności ratowania decyduje raczej waga i unikalność dokumentów niż rzeczywiste potrzeby ${ }^{14}$.

Oprócz zanieczyszczeń gazowych, wrogiem powodującym niszczenie zgromadzonych w magazynach zbiorów są wszelkiego rodzaju pyły. Pył i kurz znajdujące się w powietrzu atmosferycznym mogą zawierać substancje kwaśne, zasadowe, zarodniki grzybów i przetrwalniki bakterii. Zanieczyszczenia te osadzają się na powierzchni papieru powodując jego niszczenie, objawiające się na przykład obniżeniem $\mathrm{pH}$, powszechnie występującymi przebarwieniami ${ }^{15}$, uszkodzeniami mechanicznymi oraz skażeniem mikrobiologicznym. Dlatego właśnie tak ważne jest skuteczne i częste sprzątanie pomieszczeń magazynowych oraz systematyczne odkurzanie akt.

Zdawałoby się, że papierowe materiały archiwalne są ostatnimi obiektami, którymi mogłyby zainteresować się owady i gryzonie. Niestety tak nie jest. Niektóre z tych żyjątek ponad wszystko umiłowały sobie przechowywane w magazynach archiwalnych i bibliotecznych książki i dokumenty, czyniąc je daniem głównym swojego jadłospisu oraz polem miłosnych, owadzich igraszek. Większość z nich to chrząszcze, ale spotyka się także mniej licznych przedstawicieli gryzaków, karaczanów i motyli. Mimo swoich niewielkich rozmiarów (do kilku milimetrów długości) potrafią uczynić niepowetowane szkody, będące często wynikiem wieloletniego bytowania kolejnych pokoleń w materiałach archiwalnych $\mathrm{i}$ ich niszczenia. Słabo widoczne zmiany na początku żerowania, zaniedbania ze strony personelu opiekującego się archiwaliami, jak również sprzyjające owadom

\footnotetext{
${ }^{14}$ Według niektórych prognoz papier wyprodukowany w latach 1800-1899 zniknie z półek w ciaggu najbliższych 25 lat. Jeśli nawet prognozy te są - jak twierdzą badacze - nazbyt śmiałe, to i tak dają pewien obraz i rozmiar nieuchronnej katastrofy czekającej nasze archiwalia. O czynnikach niszczących papier, kwaśnieniu papieru i ocenie jego trwałości: B. Zyska, Tragiczne obniżenie trwałości papieru drukowanego w ksiqżkach polskich w okresie 1800-1990. Zarys problematyki, Komunikat 1, „Studia Bibliologiczne”, 6 (1992); B. Zyska, Ochrona zbiorów bibliotecznych przed zniszczeniem, Czynniki niszczqce materiaty w zbiorach bibliotecznych, t. 2, Katowice 1993.

${ }^{15}$ Każdy archiwista i niejeden korzystający $\mathrm{z}$ akt miał do czynienia $\mathrm{z}$ materiałem archiwalnym, który sprawiał wrażenie - mówiąc obrazowo - jakby był wyjęty z komina. A wszystko to właśnie za sprawą pyłów np. sadzy i zalegającego całymi latami na aktach kurzu.
} 
warunki klimatyczne w magazynach, przyczyniają się niekiedy do niespodziewanego i masowego wysypu dojrzałych form owadów. W konsekwencji powstaja trudne do opanowania zniszczenia, wymagające dużego nakładu konserwatorskiej pracy.

Owady przedostają się do zbiorów, głównie z powodu nieuwagi i zaniedbania, na przykład wraz z zainfekowanymi obiektami (nowymi nabytkami biblioteki czy archiwum), mogą również zostać przyniesione przez personel archiwalny $\mathrm{z}$ innych, zainfekowanych wcześniej magazynów. Skutki takich zaniedbań widoczne są dopiero po jakimś czasie. Uskrzydlone osobniki dorosłe są w stanie przemieszczać się wyszukując sobie najlepsze miejsca do złożenia jajeczek i jednocześnie najbogatsze w pożywienie dla larw wyklutych z jajeczek. W tren sposób dochodzi do zaatakowania całego zbioru.

Głównym owadzim przysmakiem są kleje introligatorskie z opraw książkowych, składniki, z których wytworzona jest sama kartka papieru (ścier drzewny i kleje) oraz materiały, w które oprawione są takie książki, czyli płótno, skóra itp. Dlatego śladów po owadach należy szukać właśnie w miejscach nasyconych klejami. Najbardziej powszechne owady w magazynach archiwalnych to: chyba najczęściej występujący - żywiak chlebowiec, czyniący największe szkody wśród archiwalnych tomów oraz pustosz kradnik. Kołatki zjadają nie tylko książki, ale i drewno. Rybik cukrowy - nieduży srebrzysty owad, popularny i powszechnie występujący na przykład w naszych domowych łazienkach, żywi się najchętniej celulozą i zawartymi w niej klejami, często także czyni wielkie szkody w zbiorach fotografii. Co robią mole z książkami wie chyba każdy.

Wszystkie te i wiele innych owadów, do życia i rozmnażania potrzebują wilgoci i ciepła. Dlatego, również z tego powodu, utrzymywanie tych parametrów na opisanym już wcześniej poziome jest bardzo ważne.

Jak wygląda mysz i szczur, które o dziwo również zjadają archiwalne książki, każdy wie. Ślady żerowania tych gryzoni można poznać po ogromnych dziurach, dosłownie wygryzionych w bloku bądź brzegu księgi.

Drobnoustroje, które wraz z kurzem zasiedlają powierzchnię materiałów archiwalnych zgromadzonych $\mathrm{w}$ magazynach, to zbiór różnorakich rodzajów i gatunków, stanowiących przypadkowe zbiorowisko form wegetatywnych i przetrwalnych. Przemieszczają się wraz z ruchami powietrza i osadzają w momentach jego bezruchu. Wymagania tych organizmów są różne, ale przy pierwszej okazji zawilgocenia powierzchni kiełkują wszystkie, korzystając z zapasów obecnych w zarodnikach, po czym przy życiu pozostają tylko te, które są zdolne do korzystania $z$ obecnych $w$ tym miejscu materiałów. Cała reszta ginie w ciagu pierwszej doby. Pozostałe organizmy, które umieją wykorzystać dla siebie podłoże na jakim się znajduja, w ciagu następnych 48 godzin wytwarzają zwykle niepoliczalne ilości zarodników zdolnych do życia na zasiedlonej powierzchni. Natomiast każdy zarodnik jest potencjalnie zdolny do wytworzenia kolonii i niepoliczalnych ilości komórek potomnych.

Mikrobiologiczny rozkład celulozy następuje na skutek działania specyficznych enzymów wytwarzanych przez grzyby lub bakterie. Enzymy te są wydzielane przez drobnoustroje tylko w obecności celulozy, której podstawowymi elemen- 
tami strukturalnymi są wzajemnie ze sobą połączone cząsteczki glukozy. Podczas ataku enzymy uwalniają z celulozy glukozę, która jest zużywana przez mikroorganizmy stanowiąc dla nich źródło węgla niezbędne do ich wzrostu i rozwoju. Mechanizm oraz szybkość rozkładu celulozy mogą być różne w zależności od mikroorganizmów atakujących oraz warunków, w jakich one działają. Zniszczenia spowodowane przez grzyby i bakterie objawiają się głównie zmianą zabarwienia i nieprzyjemnym zapachem. Przyczynami zabarwienia może być chemiczna reakcja ubocznego produktu metabolizmu organizmu atakującego $\mathrm{z}$ barwnikiem lub substancje wydzielane przez mikroorganizmy. W przypadku bakterii atak przebiega od powierzchni do wnętrza włókna. Grzyby natomiast przenikają przez ścianę włókna do lumenu, bądź też zarodniki dostają się do światła włókna przez pęknięcia ściany. Grzybnia rośnie z wnętrza w kierunku ściany włókna celulozowego i dzięki wydzielanym enzymom celulolitycznym powoduje jej zniszczenie, a następnie zaczyna wytwarzać zarodniki na jego powierzchni.

Zarówno bakteryjny jak i grzybiczy rozkład celulozy, jest ściśle zlokalizowany i występuje tylko w miejscu bezpośredniego zetknięcia włókna $\mathrm{z}$ organizmem lub w jego pobliżu. W korzystnych dla ,agresora” warunkach (zwykle wystarczy odpowiednio wysoka wilgotność i temperatura) atak jest szybki i niestety skuteczny, czego efektem są często nieodwracalne zmiany nie tylko w wyglądzie, ale $\mathrm{i}$ samej strukturze papieru.

Spośród mikroorganizmów największą rolę w rozkładzie celulozy odgrywają grzyby. W warunkach mało sprzyjających ich obfitemu wzrostowi i aktywnej działalności metabolicznej grzyby rozwijają się powoli, nie zarodnikują, na papierze tworzą plamy o różnym nasileniu zabarwienia i wielkości. Plamy takie, mimo swej tęczowej gamy barwnej, często dotkliwie szpecą karty ksiąg, map czy grafik i są niezwykle trudne do usunięcia. Często, mimo że pozornie wyglądają niegroźnie - na przykład jak dawno temu rozlana herbata, są objawem poważnej choroby naszej książki, niebezpiecznej nie tylko dla niej, ale także dla nas samych.

W kontekście samych akt czynnik ludzki jest niestety na nieco dalszym planie, ale w kontekście wykonywanej przez archiwistów pracy jej komfort i bezpieczeństwo są na pierwszym miejscu. Często niestety magazyny i przechowywane w nich akta nie są w najlepszym ,zdrowiu” czy to z uwagi na dawne zaniedbania i wynikające z nich konsekwencje, czy też na niemożliwość zapewnienia wystarczająco dobrych warunków przechowywania, czy po prostu z powodu zwykłej ludzkiej nieuwagi. Efektem owych zaniedbań jest potencjalne możliwe zainfekowanie naszych magazynów i cały szereg konsekwencji o charakterze patogennm (biologicznych, chemicznych, zdrowotnych, toksykologicznych), zagrażających $\mathrm{z}$ każdej strony, zaczynając od powietrza w magazynach przez ściany, regały, półki, leżące na nich książki oraz zagrażających przede wszystkim ludziom w sposób jak najbardziej bezpośredni.

Szczególnie niebezpieczne są konnidia (strzępki z zarodnikami) grzybów o charakterze alergotwórczym, takich jak: Penicillium, Alternaria, Fusarium i Cladosporium oraz grzybów z rodzaju Aspergillus wytwarzających toksyny. Oligotroficzny i saprofityczny charakter grzybów stwarza im możliwość rozwoju w niemal każdym obiekcie budowlanym na różnych podłożach. Jedynym warunkiem 
koniecznym do tego jest stosunkowo wysoka wilgotność względna powietrza. Materiały przechowywane w pomieszczeniach archiwalnych, a w szczególności papier, stanowią dogodne środowisko dla wzrostu różnych grup pleśni. Owemu wzrostowi towarzyszy wysoka aktywność metaboliczna, która związana jest zwykle z produkcją wtórnych metabolitów, z których część może działać szkodliwie również na człowieka. niezależnie od tego czy struktury te są żywe czy martwe. Również pełnią one prawdopodobną rolę czynnika etiologicznego w powstawaniu chorób o charakterze przewlekłym takich jak ,syndrom chorego domu” ${ }^{16}$ lub „syndrom chronicznego zmęczenia"17.

Badania ostatnich lat dowiodły, że możliwość wywołania mikotoksykozy drogą oddechową jest znacznie większa niż drogą pokarmową. W pierwszym przypadku toksyna trafia bezpośrednio do krwioobiegu i w związku z tym jej dawka potrzebna do wywołania reakcji chorobowej jest znacznie mniejsza niż w przypadku drogi pokarmowej. Wykazano również, że niektóre toksyczne metabolity grzybów uwalniane są w postaci związków lotnych. Wytwarzają je głównie gatunki Aspergillus i Penicillium powszechnie występujące w budynkach użytkowych, czyli między innymi muzeach, bibliotekach i archiwach ${ }^{18}$.

Mikotoksykozą nazywamy zatrucia: podostre, ostre i przewlekłe (chroniczne) wywołane wprowadzeniem toksyn grzybowych do organizmu człowieka. Zatrucia ostre charakteryzują się szybkim rozwojem szkodliwych zmian w organizmie, powstających w ciągu krótkiego czasu po wprowadzeniu jednorazowej dawki trucizny dożołądkowo, inhalacyjnie lub po naniesieniu na skórę. Najbardziej poznane mikotoksykozy to gastro-, hepato-, nefro- i neurotoksykozy ${ }^{19}$.

W zatruciach prostych szkodliwe zmiany w organizmie występują mniej gwałtownie po przyjęciu jednej bądź kilkakrotnej dawki. Zatrucia przewlekłe powstają wskutek działania małych dawek trucizny podawanych przez dłuższy okres, na ogół pod wpływem kumulacji trucizny w organizmie.

Substancje toksyczne zanieczyszczające środowisko człowieka występują przeważnie $\mathrm{w}$ tak małych stężeniach, że wywołują tylko działanie przewlekłe. $\mathrm{Na}$ ich szkodliwe stężenie w organizmie może wskazywać współczynnik IgE, przekraczający w badaniu krwi dopuszczalne normy ${ }^{20}$. Teoretycznie, lecz z du-

${ }^{16}$ Ang. Sick Building Syndrom, jest to zespół zaburzeń stanu zdrowia spowodowany występowaniem grzybów pleśniowych w pomieszczeniach, w których przebywają (pracują) ludzie.

${ }^{17}$ Ang. Chronic fatigue-like syndrome; wystepujacy w skutek przewlekłego zatrucia mykotoksynami

${ }^{18}$ J. Syguła-Cholewińska, B. Błyskal, Mikroflora powietrza w muzealnych salach wystawienniczych, w: Rozkład i korozja mikrobiologiczna materiałów technicznych, Łódź 2003.

${ }^{19}$ M. Piątek, R. Piątek, Biotoksykologiczne metody stosowane do oceny zagrożenia mikotoksycznego, w: Rozkład i korozja mikrobiologiczna materiałów technicznych, Łódź 2003.

${ }^{20}$ Immunoglobuliny E (IgE, reaginy, atopiny). W „,naturalnej” reakcji immunologicznej IgE stanowią przeciwciała szczególnie istotne $\mathrm{w}$ obronie przeciwpasożytniczej, co wiąże się z indukcją wydzielania histaminy przez bazofile i eozynofile. Te same reakcje są odpowiedzialne za rozwój alergii, która powstaje, gdy IgE łączą się z nieszkodliwymi antygenami, czyli alergenami i uruchamiają gwałtownie reakcje przeciwpasożytnicze. Badanie poziomu IgE może być także skuteczne w diagnostyce chorób alergicznych i pasożytniczych. 
żym prawdopodobieństwem, początkowo niegroźne objawy takie jak: zmęczenie, ból głowy, biegunki, bóle mięśni, katar, częste zachorowania podobne do grypy, mogą ujawnić się w postaci groźnego efektu chronicznego (przewlekłego) zatrucia, a w rezultacie uszkodzenia nerek, wątroby, czy nawet przeróżnych zaburzeń tych narządów o charakterze nowotworowym a w najgorszym wypadku - niestety raka $^{21}$.Długotrwała praca $\mathrm{w}$ warunkach narażenia na alergizujące oraz toksyczne działanie bioaerozoli, czyli pyłów o charakterze organicznym powstających przy codziennych rutynowych czynnościach z potencjalnie zakażonymi aktami, może być przyczyną wystąpienia objawów wyżej wymienionych schorzeń ${ }^{22}$.

Prawda jest taka, że „apokaliptyczne zarazy” czyhające w zainfekowanych aktach na archiwistów i magazynierów, na co dzień nie zabijają ich masowo. Odnotowane przypadki objawów zaburzeń o charakterze alergicznym, wśród personelu archiwalnego nie są raczej plaga, (przy czym należy podkreślić słowo odnotowane!), nie mniej jednak zdarzają się i objawiają w naprawdę nieprzyjemny i uciążliwy sposób.

Dlatego właśnie - i tu ze względu nie tylko na dobro akt, ale przede wszystkim ze względu na nasze własne dobro i bezpieczeństwo, należy bezwzględnie przestrzegać pewnych ściśle określonych zasad pracy w pomieszczeniach archiwalnych oraz stosować konieczne środki ochrony osobistej.

O wielu podstawowych zasadach profilaktycznych już wspominałem niemniej jednak uważam, że zwrócenie na nie szczególnej uwagi jest niezwykle istotne.

Profilaktyka - czyli zapobieganie, jest często jedynym narzędziem, jakim tak naprawdę dysponujemy, zwłaszcza kiedy wielkość naszego zbioru przekracza możliwości „dotknięcia” go kartka po kartce czy nawet tom po tomie w czasie, który pozwalałby na opanowanie całości na raz.

Fartuchy, rękawiczki i maski to podstawowe środki ochrony osobistej, w jakie powinien być wyposażony każdy, kto wchodzi do magazynu archiwalnego. Spełniają one podwójną rolę - zabezpieczają personel archiwalny przed „niezdrowymi rzeczami" znajdującymi się w pomieszczeniach magazynowych oraz zabezpieczają akta przed personelem, który - całkiem niechcący, przez niewiedzę bądź nieuwagę mógłby spowodować zakażenie zdrowych akt „niezdrowymi rzeczami" pochodzącymi z innych, zakażonych akt i magazynów. Niezwykle ważną zasada profilaktyczną jest systematyczne, codzienne kontrolowanie temperatury i wilgotności względnej powietrza w pomieszczeniach magazynowych. Ta prosta czynność często pomaga zapobiec wspomnianym wcześniej naprawdę poważnym katastrofom. Podobnie jest z kontrolowaniem nowych akt, które trafiają do naszych magazynów archiwalnych. Czynność ta pomaga zapobiec infekcji „nieskażonych"23 biologicznie materiałów, przez potencjalnie „chore” akta. Kolejną bardzo ważną czynnością profilaktyczną - ze względu na zazwyczaj szkodliwy skład

${ }^{21}$ Toksykologia współczesna, red. W. Seńczuk, Warszawa 2002, s. 888.

${ }^{22}$ Ewa Krysińska-Traczyk, Skażenie księgozbiorów archiwum grzybami pleśniowymi oraz ocena ich potencjalnej patogenności, w: Medycyna Pracy, t. 45, z. 6, 1994.

${ }^{23}$ Badania dowodzą, że nie ma akt czystych biologicznie. Sam proces produkcji papieru nie jest sterylny a poza tym nigdy nie wiemy, w jakich warunkach były przechowywane nieznane nam wcześniej akta, które właśnie trafiają do naszego magazynu. 
pyłów różnego pochodzenia, o czym już pisałem - jest odkurzanie akt. A higiena - proste i częste mycie rąk - jest ważna nie tylko dla akt ale i dla archiwisty.

Zabezpieczanie materiałów archiwalnych to ogromny zakres czynności obejmujący zarówno działania profilaktyczne jak i całkiem skomplikowane - często specjalistyczne zabiegi konserwatorskie. Działania profilaktyczne chronią materiał archiwalny na przyszłość, zapobiegając jego możliwej destrukcji na różnych poziomach przechowywania i użytkowania. Natomiast zabezpieczanie jest działaniem dotyczącym bezpośredniej ochrony konkretnej jednostki archiwalnej. Działania te często polegają na dokonywaniu bardzo ważnych i jednocześnie bardzo prostych zabiegów introligatorskich, takich jak robienie obwolut czy opakowań ochronnych, ale i na zszywaniu ,rozlatujących się” jednostek albo sklejaniu podartych kart, co bywa naprawdę trudne i skomplikowane. Samo pakowanie archiwaliów w pudła i teczki z bezkwasowej, litej tektury jest niezwykle istotną i pomocną czynnością zabezpieczającą względnie materiały archiwalne przed szkodliwymi pyłami oraz uszkodzeniami mechanicznymi. Także użytkowanie takich akt staje się o wiele bezpieczniejsze.

Co do czynności introligatorskich czy renowatorskich takich jak np.: sklejanie przedarć czy zszywanie luźnych kart to absolutnie nienaruszalną, żelazną zasadą jest tu starożytna sentencja: primum non nocere - po pierwsze: nie szkodzić! Jeśli nie bardzo jesteśmy pewni jak i czym najbezpieczniej wykonać naprawę uszkodzonego dokumentu, lepiej jest nie zrobić nic niż użyć materiału o nieznanym składzie chemicznym. Wszelkie ogólnodostępne taśmy klejące i zwykłe kleje biurowe zawierają substrancie szkodliwe dla materiałów archiwalnych. Zatem „naprawa" cennego dokumentu takimi właśnie materiałami może być tylko pozornie pożyteczna, w konsekwencji może doprowadzić do jego nieodwracalnego zniszczenia.

Konserwacja papieru to rzemiosło artystyczne, u podstaw którego leży wiele różnych, często trudnych i skomplikowanych dziedzin nauki. Wieloletnie, zwykle bardzo kosztowne doświadczenia i analizy oraz wyniki badań z zakresu owych dziedzin nauki ostatecznie realizują się w bezpośrednich działaniach konserwatorskich w zakresie konserwacji właściwej, renowacji oraz profilaktyki materiałów archiwalnych. Wszystkie te działania mają na celu takie zabezpieczanie dokumentów, aby ingerując $w$ ich strukturę fizyczną i chemiczną w możliwie jak najmniejszy sposób, trwale, rzetelnie i bezpiecznie dokonać zachowania ich formy, kształtu, koloru i przede wszystkim treści. Nie zawsze jest to możliwe z wielu powodów - nie zawsze rozmiar i rodzaj zniszczeń, jakie dotykają dokumenty, pozwala na przywrócenie im stanu dawnej świetności. Jednakże zadaniem konserwatorów, renowatorów i archiwistów jest możliwie najlepsze zabezpieczenie i zachowanie tego, co pozostało. Często jest to proces bardzo skomplikowany, niezwykle pracochłonny i długotrwały, ale każdy choćby najmniejszy fragment naszej historii, kultury i tradycji jest warty zachowania. Poza tym bycie konserwatorem czy renowatorem to bardzo poważna i odpowiedzialna rola, ale i naprawdę fascynująca, a bywa, że i emocjonująca przygoda, dzięki której - często z przysłowiowego prochu, powstają rzeczy naprawdę wielkie i ważne.

Mam nadzieję, że lektura tego tekstu rozwieje nieco mroki i tajemnice wie- 
dzy z zakresu profilaktyki i zabezpieczania materiałów archiwalnych. Informacje na ten temat często są trudne do zlokalizowania i zdobycia, a na pewno są ,porozrzucane" po ogromnej ilości czasopism, naprawdę mądrych książek i innych publikacji z zakresu różnych dziedzin nauki. Starałem się zebrać w jedną całość możliwie najświeższe informacje i wszystkie te rzeczy, które moim zdaniem są potrzebne do tego, żeby w sposób prosty, czytelny i jasny zrozumieć, z czym w swojej codziennej praktyce ma do czynienia bibliotekarz, magazynier, archiwista czy renowator. Mam jednak świadomość tego, że wiedza zapisana powyżej ma charakter ogólny i raczej stanowi materiał do dalszych dociekań i punkt wyjścia do zdobywania zawodowych doświadczeń z zakresu profilaktyki i zabezpieczania materiałów archiwalnych. Najważniejsza bowiem, w tej jakże fascynującej profesji jest nie teoria, lecz przede wszystkim praktyka. Niemniej jednak teoria stanowi całkiem solidny fundament wszelkich praktyk, dlatego zachęcam do śledzenia najnowszych publikacji dotyczących konserwacji, renowacji i działań profilaktycznych zabezpieczających papier oraz do mądrego i odpowiedzialnego wprowadzania tej wiedzy w życie.

\section{Bibliografia - wybrane pozycje.}

Polska Norma PN-ISO 11799, Informacja i dokumentacja. Wymagania dotyczące warunków przechowywania materiałów archiwalnych i bibliotecznych, Warszawa, czerwiec 2006.

ISO 9706:1994, Information and documentation - Paper for documents - Requirements for permanence (Informacja i dokumentacja - Papier na dokumenty - Wymagania odnośnie trwałości).

Strzelczyk A. B., Mikrobiologiczne zniszczenia zbiorów bibliotecznych. Przyczyny i objawy destrukcji, w: Studia bibliologiczne, t. 10, Prace Naukowe Uniwersytetu Ślaskiego, nr 1618, Katowice 1997.

Strzelczyk A. B., Karbowska-Berent J., Drobnoustroje i owady niszczqce zabytki i ich zwalczanie, Toruń 2004.

Toksykologia wspótczesna, red. W. Seńczuk, Warszawa 2002.

Zyska B., Ochrona zbiorów bibliotecznych przed zniszczeniem, Czynniki niszczqce materialy w zbiorach bibliotecznych, t. 2, Katowice 1993.

Zyska B., Zagrożenia mikrobiologiczne w budynku, Warszawa 1999.

Materiały z sesji: ,, Rozkład i korozja mikrobiologiczna materiałów technicznych”, Łódź 2001, Łódź 2003.

$\mathrm{W}$ pacy korzystałem również z materiałów udostępnionych mi przez pana John`a Webster`a - British Library, National Preservation Office oraz z informacji zawartych w poniżej opisanych witrynach internetowych.

http://www.archiwa.gov.pl

(strona poświęcona różnym aspektom pracy archiwów w Polsce. W zakładce Konserwacja informacje dotyczące zadań, projektów i osiągnięć konserwatorskich) 
http://www.knaw.nl/ecpa/grip/search.html

(strona GRIP - Gateway for Resources and Information on Preservation - wrota do zasobów i informacji dotyczących zabezpieczania. Zwiera bazę danych dotyczącą zabezpieczania zbiorów archiwalnych i bibliotecznych oraz literaturę, linki do projektów konserwatorskich, grup dyskusyjnych oraz stron internetowych poświęconych wielu różnym aspektom profilaktyki i konserwacji)

http://palimpsest.stanford.edu/

(strona CoOL - Conservation On Line - projekt Departamentu Konserwacji Biblioteki Uniwersytetu Stanforda. Zawiera bibliotekę tekstów dotyczących wielu aspektów konserwacji materiałów archiwalnych, bibliotecznych i muzealnych)

http://www.ifla.org/VII/s19/index.htm

(strona IFLA - International Federation of Library Associations and Institutions - Międzynarodowa Federacia Stowarzyszeń Bibliotek i Instytucji. Zwiera informacje o programach ochrony oraz informacje dotyczące najnowszych osiaggnięć w dziedzinie zabezpieczania i konserwacji zbiorów bibliotecznych $\mathrm{i}$ archiwalnych)

http://www.bl.uk/services/preservation

(strona NPO - National Preservation Office - narodowe biuro konserwacji. Witryna oddziału Biblioteki Brytyjskiej, zajmującego się upowszechnianiem wiedzy z zakresu profilaktyki i konserwacji materiałów muzealnych, bibliotecznych i archiwalnych.) 